\title{
Derajat Demokratisasi Desa di Indonesia
}

\author{
Noman Kresna Martha \\ Sekretaris Kecamatan Kedungpring \\ Kabupaten Lamongan
}

\begin{abstract}
National democracy will be strong if it is supported by democracy at the grassroots level. Nearly the last two decades, counting since the 1998 reforms, public attention has focused on democratic systems and journeys at the national level. While in the lowest society, democracy has not been a prominent agenda either in regulation or in the real political process. Village Communities, for example, have so far only been 'involved' in regional and national 'democratic' events, such as in elections, direct Pemilukada, or become objects of regulation in regional autonomy. At the level of jargon, democracy is often interpreted as a government of and for the people, meaning government by the people and carried out by representatives who are freely elected by the people. Democratization, because it is an effort to achieve democratic life through democratic means. Democracy is not achieved through a non-democratic process and the application of democratic methods does not always struggle in a democratic situation.
\end{abstract}

\section{Keywords: Democratization, Village, Indonesia}




\section{Pendahuluan}

Demokrasi nasional akan kokoh apabila disokong oleh demokrasi di tingkat akar rumput. Hampir dua dekade terakhir, dihitung sejak reformasi 1998, perhatian publik terarah pada sistem dan perjalanan demokrasi di tingkat nasional. Sementara di masyarakat paling bawah, demokrasi belum menjadi agenda yang menonjol baik dalam regulasi maupun dalam proses politik riil. Masyarakat Desa misalnya, sejauh ini hanya 'dilibatkan' dalam perhelatanperhelatan "demokratis" daerah maupun nasional, seperti dalam Pemilu, Pemilukada langsung, atau menjadi objek pengaturan dalam otonomi daerah.

Pada level jargon, demokrasi sering diartikan sebagai pemerintahan dari dan untuk rakyat, artinya pemerintahan oleh rakyat dan dilakukan oleh wakil-wakil yang dipilih bebas oleh rakyat. Demokratisasi, karena itu merupakan upaya mencapai kehidupan demokrasi melalui cara-cara demokratis. Demokrasi tidak dicapai melalui proses non-demokratis dan penerapan caracara demokratis tidak senantiasa berjuang pada situasi demokratis (Samadhi, 2014).
Sebagai sebuah tujuan, demokrasi diidealkan sebagai sistem yang menjamin keberlangsungan kontrol rakyat (popular control) terhadap urusan publik (publikaffairs) atas dasar prinsip kesetaraan warga negara (equalrights). Dari pengertian itu, setidaknya ada tiga dimensi yang melekat pada pengertian demokrasi, yaitu kontrol publik, utusan publik, dan kesetaraan warga negara. Maka, pertanyaan- pertanyaan terpenting untuk mendiagnosis situasi dan kondisi demokrasi adalah: (1) siapa demos? (2) bagaimana urusan publik dirumuskan? Dan (3) bagaimana kontrol publik dijalankan? (Pratikno \& Kurniawan, n.d.) Dengan adanya sistem demokratisasi akan berdampak pada masyarakat, dimana demokrasi memberi peluang pengelolaan konflik secara efektif melalui manajemen konflik. Disamping itu, sistem demokrasi mendorong pelayanan publik yang lebih baik karena adanya kontrol secara efektif dari masyarakat terhadap pemerintah.

Menurut Syafiie dalam (Sulaksono, 2016) jika dilihat dari segi pelaksanaannya bahwa demokrasi terbagi menjadi dua model yaitu: pertama, demokrasi langsung: yang terjadi ketika rakyat dalam mewujudkan 
atau membuat suatu keputusan secara langsung. Kedua, demokrasi tidak langsung: ketika rakyat untuk mewujudkan kedaulatannya tidak secara langsung berhadapan dengan pihak eksekutif, melainkan melalui lembaga perwakilan. Pada demokrasi tidak langsung, lembaga parlemen dituntut kepekaannya terhadap berbagai hal yang berkaitan dengan kehidupan bermasyarakat dalam hubungannya dengan pemerintah atau negara. Demokrasi tidak langsung disebut juga dengan demokrasi perwakilan.

Gagasan demokrasi bersifat universal. Namun, dalam penerapannya demokrasi prosedural sangat bervariasi. Hal tersebut dipengaruhi oleh adanya dua tradisi yang berbeda yaitu, pemikiran liberal dan komunitarian. Dalam tradisi liberal, demokrasi prosedural diukur dengan hanya tiga nilai penting, yaitu kompetisi, liberalisasi dan partisipasi yang elemen ini berbasis pada individualisme dan semangat kebebasan individu.

Adanya demokrasi komunitarian telah hadir sebagai kritik terhadap demokrasi liberal karena demokrasi liberal dinilai menjadi universal terhadap praktik demokrasi prosedural. Masyarakat telah menilai bahwa demokrasi merupakan kebebasan individu, yang mana dilakukannya pemilihan secara bebas dan partisipasi. Demokrasi secara partikulatif dengan memperhatikan keragaman budaya dan struktur sosial dipakai dalam tradisi komunitarian yang peka terhadap masalah ini. Menurut dua penganut demokrasi komunitarian, dalam hal ini (Walzer, 1984) menyatakan bahwa semangat individualisme liberal tidak memberikan landasan yang kokoh bagi kebebasan dan kesetaraan warga dalam bingkai demokrasi komunitas.

Demokrasi desa lebih tepat dijelaskan dengan pendekatan demokrasi komunitarian karena kegagalan demokrasi prosedural liberal dalam mewadahi partispasi publik. Demokrasi liberal mereduksi praktik demokrasi hanya dalam kerangka pemilihan pemimpin dan lembaga perwakilan sebagai wadah partisipasi publik. Format demokrasi perwakilan yang didesain dan dibingkai dalam peraturan akan menimbulkan apa yang disebut sebagai oligarki elite (Michels, 1915). Segelintir elite mengendalikan pemerintahan dan pembuatan keputusan itu umumnya bersikap konservatif dan punya kepentingan yang tercabut dari kontituennya, tetapi mereka selalu mengklaim mewakili rakyat banyak. 
Perhelatan-perhelatan tersebut tentu memiliki maksud dan tujuan tersendiri yang tak kalah penting, diantaranya sebagai pewujudan demokrasi dalam politik nasional. Akan tetapi demi kuatnya demokrasi secara nasional, penumbuhan kesadaran dan pembelajaran demokrasi membutuhkan upaya yang lebih massif dan langsung menyentuh kehidupan masyarakat Desa. Di antaranya melalui demokratisasi Desa.

Kekosongan regulasi Negara yang mendorong demokrasi di tingkat masyarakat paling bawah diisi oleh UU No. 6 Tahun 2014 tentang Desa. UU No. 6 Tahun 2014 - selanjutnya disebut UU Desa - secara spesifik memerintahkan Kepala Desa dan BPD (Badan Permusyawaratan Daerah) untuk melaksanakan kehidupan demokrasi. Kewajiban serupa berlaku bagi Desa, yaitu untuk mengembangkan kehidupan demokrasi. Itu berarti, UU Desa tengah mensinergikan demokrasi sebagai kewajiban bagi elit Desa (Kades dan BPD) dengan pengembangan tata sosial dan budaya demokrasi masyarakat Desa secara keseluruhan. Apabila sinergi keduanya dapat terjadi, kokohnya demokrasi secara nasional menjadi mungkin terwujud.
Ikhwal yang harus diperjelas adalah: mengapa demokratisasi Desa penting ? Tidakkah proses demokratisasi yang masih terus berlangsung sampai saat ini di tingkat nasional cukup mengantarkan Desa menjadi demokratis ? Lantas, bagaimana demokratisasi Desa akan dilakukan ? Tiga pertanyaan tersebut mewakili gambaran umum apa yang akan diukur dalam tulisan ini.

\section{Desentralisasi Melalui Demokrasi}

$$
\text { Selanjutnya }
$$

mengenai

desentralisasi dan demokrasi. Dalam sejarahnya, isu desentralisasi di Indonesia terkait isu demokrasi. Ketika mualai dilakukannya reformasi pada tahun 1998, Indonesia berada dalam era transisi kekuasaan dari otokrasi ke demokrasi. Pada masa transisi muncul desentralisasi melalui kebijakan otonomi daerah. Namun, apakah desentralisasi dan demokrasi secara konseptual memiliki kesamaan? karena, pada tahap kemunculannya, desentralisasi disamakan dengan proses demokratisasi dan kebangkitan masyarakat sipil. Namun menurut para pakar, antara keduanya terdapat perbedaan hal tesebut dijelaskan oleh (Marijan, 2006) dimana desentralisasi dan demokrasi adalah dua konsep yang berbeda. 
Pendapat senada diungkapkan (Baswedan, 2007) bahwa desentralisasi pusat-daerah adalah hal yang berbeda dari demokrasi. Namun, dalam konteks di Indonesia, desentralisasi merupakan bagian dari demokratisasi.

Secara umum desentralisasi lebih merujuk pada relasi antara pemerintah pusat dan daerah. Sementara demokrasi berkaitan dengan proses dan prosedur berbagai proses politik yang melibatkan rakyat baik tingkat pusat maupun daerah (Baswedan, 2007). Perbedaan desentralisasi dengan demokratisasi bukan hanya pada level konseptual. Tetapi pada level praktik keduanya nampak tidak memiliki kesamaan. Secara praksis operasional, desentralisasi, misalnya bisa dijumpai di negara-negara yang pemerintahannya otoriter atau totaliter. Desentralisasi bisa juga dipraktikkan dan diadopsi oleh negara meskipun menggunakan sistem politik yang otoritarian atau semiotoritarian.

Menurut (Nordholt \& van Klinken, 2007) Perubahan yang terjadi dari pemerintahan yang sentralistik ke pemerintahan desentralistik tidak sama dengan pergeseran dari pemerintahan otoriter ke pemerintahan demokratis, hal tersebut juga tidak secara otomatis mengisyaratkan pergeseran dari negara yang kuat ke negara masyarakat sipil yang kuat. Dalam hal ini (Crook, 2000) menegaskan bahwa pada akhirnya desentralisasi bisa terlepas dari makna demokrasi. Pandangan pakar lain juga menegaskan perbedaan konseptual antara demokratisasi dan desentralisasi yaitu (Rondinelli, 1983) mengatakan, meskipun desentralisasi dan demokratisasi pada dasarnya adalah konsep yang bukan berdiri sendiri, tapi keduanya juga bukanlah konsep yang saling berkaitan.

Meski secara konseptual berbeda dan dalam praktiknya belum tentu seirama, usaha untuk menyingkronkan dan mempertemukan kedua konsep, baik di level teoritis dan praksis, senantiasa dilakukan. Minimal ada kesaling terkaitan dan relevansi di antara kedua konsep tersebut, sehingga keduanya menciptakan sistem politik yang saling memperkuat. Secara prosedural kan desentralisasi harus dilakukan dalam kerangka demokratisasi. Bahkan dalam UU.No.32/ 2004 tentang otonomi daerah, prinsip demokrasi menjadi salah satu pertimbangan dalam pembentukan UU tersebut.

Dalam undang-undang otonomi daerah sebelumnya yaitu UU No. 22/1999, secara tegas dikatakan bahwa prinsip demokrasi menjadi landasan dalam pelaksanaan otonomi daerah, di 
samping prinsip - prinsip lain. Meski UU yang nampak demokratis itu dalam impelemntasinya "berantakan" karena salah asumsi dan tidak berlangsung lama UU itu direvisi dan digantikan dengan UU No.32/ 2004. yang demikian menunjukkan bahwa prinsip demokrasi menjadi dasar dalam perancangan dan pelaksanaan otonomi daerah atau desentralisasi.

Ratnawati, 2011 menjelaskan bahwa prinsip demokrasi yang menjadi dasar pembentukan dan pelaksanaan otonomi daerah. Dimana hal tersebut juga dijelaskan oleh (Nordholt \& van Klinken, 2007) mengatakan bahwa prinsip demokrasi tetap menjadi landasan penting dalam pelaksanaan UU otonomi daerah yang baru. Dalam kondisi-kondisi tertentu desentralisasi justru bersamaan dengan sistem pemerintahan yang otoriter. Dalam konteks Indonesia konsep desentralisasi dan demokratisasi selalu diusahakan untuk sinkron berjalan seirama. Hal yang sama dijelaskan oleh (Marijan, 2006) mengatakan bahwa para penganut desentralisasi politik, efisiensi efektifitas dalam pelayanan publik daerah bisa saja tidak cukup tanpa diiringi oleh adanya di daerah. Maka dari kedua konsep tersebut, diciptakanlah yang konsep baru dikenal dengan democratic decentralization, (Turner, Hulme, Turner, Hulme, \& Mccourt, 2015) menjelaskan bahwa masyarakat daerah mempunyai kedaulatan dalam devolusi kekuasaan atau kewenangan. Ketika kekuasaan atau kedaulatan didelegasikan secara devolusi, maka mekanisme akuntabilitas yang khas adalah berupa pemilihanpemilihan lokal, yang di dalamnya masyarakat daerah mempunyai kedaulatan yang lebih tinggi. Dengan konsep seperti ini, maka otonomi daerah (desentralisasi) adalah otonominya masyarakat, bukan otonominya pemerintah daerah atau elite-elite lokal saja.

Karena asasnya adalah "untuk masyarakat daerah dan bukan untuk elite daerah", maka desentralisasi dalam kebijakan otonomi daerah mempunyai titik temu dengan demokratisasi. Meski harus diakui bahwa desentralisasi yang demokratis di Indonesia jauh panggang dari api Dalam praktiknya, desentralisasi sebatas menjadi "berkah" bagi elite politik. Walaupun setidaknya, dilihat dari sisi konseptual, semangat demokrasi menjadi ruh desentralisasi. Di sinilah letak titik temu desentralisasi dan demokratisasi dalam konteks otonomi daerah di Indonesia.

Menurut (Smith, 2012) hubungan desentralisasi dan demokratisasi 
terdapat sembilan hipotesis yang dengan konsekuensi politik desentralisasi. Sembilan hepotesis itu adalah sebagai berikut: pertama, semakin terdesentralis sistem kekuasaan, maka semakin terbuka lebar peluang distribusi kekuasaan yang merata dalam komunitas. Berbeda dengan sistim sentralisasi di mana kekuasaan menggumpal dalam satu titik pusat Semangat demokrasi pun muncul dalam proses desentralisasi. Sebab kekuasaan tidak menjadi monopoli atau dominasi elite melain terbagi secara seimbang dengan masyarakat.

Kedua, semakin terdesentralisasi sebuah sistem pemerintahan. maka masyarakat akan semakin terdidik. Dengan kekuasaan yang ada dalam masyarakat maka masyarakat mempunyai kebebasan mengembangkan nalar kritisnya. Desentralisasi memberikan pemahaman kepada masyarakat tentang pentingnya kritik dan debat politik yang konstruktif, penyeleksian para wakil rakyat, dan managamen anggaran dan perencanaan dalam sebuah sistem demokrasi. Selain memicu masyarakat untuk berpikir dan mengkritisi proses politi yang berjalan, desentralisasi membuka ruang berkompetisi secara fair bagi masyarakat dalam memperebutkan kesempatan berkuasa.
Dalam proses kompetisi, masyarakat terdorong mengembangkan potensi - potensi sebagai meminjam istilah Bourdieu modal dalam politik. Bourdieu mengatakan bahwa apa yang disebut sebagai ranah adalah ranah perjuangan dalam memperjuangkan posisi dan otoritas yang legitimit, sementara logika yang mengatur perjuangan ini adalah logika modal. Hal ini tentu saja berlaku dalam ranah politik. Untuk memperebutkan posisi di ranah politik praktis, seseorang harus mempunyai modal, dan di antara modal itu adalah modal intelektual. Untuk mengakses daya intelektual masyarakat inilah, bagi Smith desentralisasi sangat mendukung.

Ketiga, semakin terdesentralisasi sebuah sistem pemerintahan, sistem itu akan semakin stabil. Stabilitas politik bisa terjamin ketika terjadi stabilitas masyarakat. Saat stabilitas masyarakat terkoyak maka sudah dipastikan stabilitas politik, baik nasional maupun lokal, akan terkoyak. Melalui desentralisasi, diharapkan masyarakat bisa meningkatkan peran sertanya dalam perpolitikan. Partisipasi dan peran masyarakat yang tinggi membuat kekuasaan atau pemerintahan memperoleh legitimasi dan kepercayaan yang besar. Sebaliknya, ketika partisipasi 
dan peran masyarakat rendah, misalkan banyak masyarakat yang golput dalam pemilu, maka kepercayaan dan legitimasi masyarakat terhadap pemerintah sangat rendah. Peran dan partisipasi adalah wujud dari kepercayaan masyarakat. Sementara kepercayaan masyarakat adalah sumber stabilitas. Kepercayaan masyarakat bisa muncul jika diberi kekuasaan untuk menentukan pilihan politiknya. Hal ini bisa ditempuh melalui kebijakan desentralisasi. Desentralisasi yang melahirkan kepercayaan masyarakat sebagai sumber stabilitas diharapkan mampu melahirkan harmoni sosial, semangat kekeluargaan dan stabilitas politik.

\section{Keempat, semakin besar desentralisasi yang diberikan maka negara semakin dekat dengan warganya.} Kedekatan pemerintah atau negara diharapkan menjadi pintu sensitifitas bagi negara terhadap aspirasi dan kepentingan rakyat. Seringkali pemerintah sebagai aparat negara berjarak dari masyarakat. Banyak elite politik yang tidak peka dengan kondisi masyarakatnya. Ketika masyarakat dilanda ketertindasan teror dan misalnya, negara sering kali absen. Hal ini membuktikan adanya jarak yang sangat dalam antara negara dan rakyat. Desentralisasi bisa menjadi pendorong negara dan elite politik, terutama elite politik lokal, untuk senantiasa peka terhadap persoalan-persoalan yang dihadapi masyarakat. Desentral diharapkan mampu menumbuhkan sensitifitas pemerintah, sebab adanya peningkatan kuantitas perwakilan lokal yang ditempatkan di pusat kekuasaan, sehingga upaya mengetahui kebutuhan lokal terpenuhi dengan cara-cara yang efektif.

\section{Demokratisasi Desa}

Demokratisasi

Desa

merupakan frase tersendiri yang sengaja dibedakan dengan demokratisasi di Desa. Demokratisasi Desa mewakili semangat UU Desa yang mengakui Desa sebagai subyek dalam payung asas rekognisi dan subsidiaritas. Pilihan frase tersebut juga dimaksudkan untuk menunjukkan bahwa Desa bukanlah ruang geografi kosong yang berjarak dari sosio budaya manusia yang tinggal di dalamnya, seperti tertangkap dari frase demokratisasi di Desa. Sebaliknya, Desa merupakan kesatuan teritorial atau wilayah yang melekat dan terikat pada kehidupan manusia di atasnya beserta tradisi dan adat-istiadat yang menggerakkan kehidupan itu. Dengan demikian, frase atau konsep demokratisasi Desa berarti 
upaya menggerakkan demokrasi dalam kekhasan Desa itu sendiri. Demokrasi dilaksanakan dan dikembangkan dalam semangat pengakuan keunikan dan kekhasan tradisi Desa.

Signifikansi atau nilai penting demokratisasi Desa dilatarbelakangi oleh dua hal. Pertama, dalam arena Desa, demokrasi merupakan upaya pendefinisian ulang hubungan antara masyarakat Desa dengan elit atau penyelenggara Pemerintahan Desa (Kades beserta perangkat dan BPD). Melalui demokrasi, di Desa pun berlaku definisi umum kekuasaan, yakni kekuasaan berasal dan berada di tangan rakyat. Dengan berpijak pada definisi tersebut berarti bahwa masyarakat atau warga Desa adalah pemilik sejati dari kekuasaan (Desa), bukan elit atau penyelenggara Pemerintahan Desa. Penyelenggara Pemerintahan Desa adalah sekedar pelaksana kekuasaan rakyat Desa, bukan pemilik kekuasaan atau apalagi pemilik Desa.

Latar belakang kedua terkait dengan kemajuan yang ditandai oleh UU Desa dalam memandang kedudukan Desa. Salah satu bagian terpenting dalam UU Desa adalah pengakuan Negara terhadap hak asal-usul Desa (disebut asas rekognisi) dan penetapan kewenangan berskala lokal dan pengambilan keputusan secara lokal untuk kepentingan masyarakat Desa (disebut asas subsidiaritas). Dengan dua asas tersebut, Desa memiliki kewenangan yang sangat besar untuk mengurus dirinya sendiri.

Dipandang dari sudut kepentingan masyarakat Desa, rekognisi dan subsidiaritas memberi peluang bagi Desa untuk mewujudkan kehendak bersama dalam semangat Desa membangun. Desa tampil sebagai subyek yang merencanakan dan menyusun prioritas pembangunannya sendiri, terlepas dari instruksi atau dikte Pemerintah ataupun Pemerintah Daerah. Sementara di sisi lain, hanya dengan rekognisi dan subsidiaritas, watak feodal dan elitisme penyelenggara Pemerintahan Desa berpeluang untuk muncul kembali (Sutoro Eko, dkk., 2014). Dalam konteks itulah, demokrasi dibutuhkan untuk mengembangkan modal sosial masyarakat Desa dalam berhadapan dan mengelola kekuasaan Desa. Melalui demokrasi pula, dapat diharapkan tumbuhnya kesadaran dalam masyarakat Desa akan posisinya sebagai sumber serta pemilik kekuasaan yang sejati. 
Rekognisi dan subsidiaritas sebagai asas pengaturan Desa membawa implikasi pada desain demokrasi yang dikembangkan di Desa. Demokrasi Desa memiliki titik tekan dan nuansa tersendiri yang tidak dapat disamarupakan dengan demokrasi di tingkat nasional. Hak asal-usul, pola sosio budaya Desa, karakteristik masyarakat Desa, dan kenyataan sosiologis masyarakat Desa menuntut adaptasi dari sistem modern apapun apabila ingin berjalan di Desa, tidak terkecuali demokrasi.

\section{Desa Sebagai Arena Demokrasi}

Demokratisasi Desa setidaknya harus memperhatikan empat hal berikut. Pertama, hubungan-hubungan sosial yang ada di Desa terbangun dari pergaulan sosial secara personal antar sesama penduduk Desa yang telah berlangsung lama. Bahkan, banyaknya Desa-desa di Indonesia yang usianya jauh lebih tua dari usia Negara Republik Indonesia menandai bahwa hubunganhubungan sosial tersebut telah sangat lama terbentuk. Apabila nasionalisme atau perasaan kebangsaan di tingkat Negara terbentuk secara imajiner, seperti danyatakan oleh seorang antropolog, perasaan sebagai sesama orang sedesa tumbuh secara empiris dan personal, yaitu hasil dari pergaulan sehari-hari termasuk dari hubungan kekerabatan. Hubungan-hubungan tersebut seringkali membentuk pola sikap dan tata cara pergaulan. Secara umum misalnya hubungan antara orang yang lebih tua dengan yang lebih muda, saudara dekat dengan saudara jauh, berkerabat atau tidak berkerabat.

Kedua, hubungan Desa dengan ruang juga berlangsung dengan intensitas yang sangat tinggi. Bagi Desa, tanah dan ruang yang mereka tinggali bukan semata-mata ruang mati yang dapat ditinggalkan sewaktu-waktu atau diolah dan diuangkan (dijual) dengan sesuka hati. Ruang bagi Desa sama pentingnya dengan kehidupan itu sendiri. Keterikatan pada ruang tersebut bukan semata-mata bersifat ekonomis, yakni sebagai sumber nafkah, melainkan tidak jarang dibarengi dengan perlakuan ruang sebagai sesuatu yang bernyawa dan hidup. Dari model keterikatan semacam itulah muncul kearifan lokal (local wisdom) yang teraktualisasi dalam bentukbentuk tindakan ramah lingkungan masyarakat Desa, penghargaan terhadap tanah, udara, dan air.

Berkait dengan itu, ketiga, pergaulan yang lama, intens, dan 
berlangsung dalam hubungan serba hidup dengan ruang, menciptakan atau pola sosio budaya Desa yang khas. Kehidupan Desa bukan berlangsungsebagai kumpulan manusia yang berhubungan secara kontraktual dan formal, melainkan sekumpulan manusia yang memiliki pengalaman bersama, sekaligus digerakkan oleh tradisi yang terbentuk dalam lintasan sejarah, dan terikat pada ruang. Setiap Desa memiliki adat-istiadat, sistem kelembagaan politik tradisional yang berbeda-beda, dan sejarahnya masingmasing. Misalnya, Banyak Desa yang masih mempergunakan trah atau keturunan sebagai rujukan penilaian siapa yang layak menjadi Kepala Desa.

Keempat, solidaritas yang terbentuk di Desa biasanya bersifat mekanis yang kental dengan nuansa kolektivistik. Dalam bentuk solidaritas semacam itu, masyarakat Desa menjadi suatu kategori subyektif tersendiri yang diikat oleh rasa kebersamaan dan saling topang. Masyarakat Desa sebagai subyek atau aktor dapat bertindak sebagaimana individu. Dalam cara pandang modernisasi-pembangunan model orde baru, sifat-sifat Desa yang semacam itu dilihat sebagai penghambat pembangunan. Sebaliknya, dalam UU
Desa sifat-sifat itu justru diakui dan diterima sebagai fakta objektif yang memiliki potensi tersendiri bagi kemajuan masyarakat Desa, termasuk dalam hal berdemokrasi.

\section{Refleksi Akhir}

Menurut analisa penulis berdasarkan berbagai penjelasan di atas maka dapat disimpulkan bahwa demokrasi desa merupakan sebuah proses yang baru saja dimulai yang mana hasilnya atau dampak dari penerapannya belum terlihat. Demokrasi merupakan proses yang bersifat seremonial, namun dalam kenyataannya bahwa masyarakat desa menerima banyak akses terutama dalam proses demokrastisasi seperti kebebesan dalam memutuskan kepentingannya.

Demokrasi desa merupakan salah satu bentuk dari pendekatan demokrasi komunitarian, yang mana menekankan terhadap pengakuan individu kepada komunitas dengan memberikan perhatian terhadap otonomi individu. Namun pada kenyataannya yang di perlihatkan bukanlah kebebasan individu, melainkan penghargaan terhadap otonomi individu dengan memberikan kesempatan kepada setiap 
individu agar mampu memaksimalkan dirinya.

Demokrasi prosedural yang terkait dengan mekanisme pembuatan keputusan, penentuan pemimpin, dan artikulasi kepen tingan masyarakat haruslah ditunjang dengan kinerja pemerin- tahan yang baik. Pokok persoalan kinerja pemerintahan yang ditemui peneliti di lokasi penelitian meliputi pengambilan kepu- tusan desa bias elite, pengelolaan keuangan yang tidak transparan dan adanya mekanisme nonbujeter, kekuasaan elite primordialistik yang cenderung untuk menekan dan memobilisasi rakyat, dan akuntabilitas pelayanan publik masih rendah. Kinerja pemerintahan desa pada masa mendatang diarahkan kepada pembentukan indikator pengontrol kinerja pemerintah desa, proses demokratisasi di segala aspek, penguatan BPD seba gai alat kontrol terhadap pemerintah, dan peningkatan partisipasi rakyat dalam pemerintahan dan pembangunan.

\section{Daftar Pustaka}

Baswedan, A. (2007). Kata pengantar dalam Politik Lokal di Indonesia. Jakarta: KITLV- Jakarta dan Yayasan Obor Indonesia.
Crook, R. (2000). Decentralization, (11).

International Bank for Reconstruction and Development. (1997). World development report. The State in a Changing World. Na.

Marijan, K. (2006). Demokratisasi di daerah: pelajaran dari pilkada secara langsung. Pustaka Eureka dan PusDeHAM.

Michels, R. (1915). Political parties: A sociological study of the oligarchical tendencies of modern democracy. Hearst's International Library Company.

Nordholt, H. S., \& van Klinken, G. (2007). Politik Lokal di Indonesia (trans.

Renegotiating boundaries local politics in post-Suharto Indonesia. Jakarta: KITLV and YOI.

Pratikno, \& Kurniawan, N. I. (n.d.). Struggle to Gain Representation : Mixed Politics

in Democratising Indonesia.

Ratnawati, T. (2011). Antara "Otonomi" Sultan Dan "Kepatuhan" Pada Pusat Di Era Reformasi: Studi Kasus Daerah Istimewa Yogyakarta (DIY). Governance (Jurnal Ilmu Pemerintahan). 
Rondinelli, D. A. (1983). Decentralization and development: Policy implementation in developing countries, (Sage Publications).

Samadhi, W. P. (2014). Mengembalikan Publik pada Demokrasi. Jakarta: Kepustakaan Populer Gramedia.

Smith, B. C. (2012). Desentralisasi: Dimensi Teritorial Suatu Negara. Jakarta: Masyarakat llmu Pemerintahan Indonesian (MIPI).

Sulaksono, T. (2016). Menggugat Relasi Partai Politik dan Demokrasi di Indonesia

PascaOrde Baru.

Turner, M., Hulme, D., Turner, M., Hulme, D., \& Mccourt, W. (2015). Governance, administration, and development: Making the state work.

Walzer, M. (1984). Deterrence and democracy. New Republic. 